\title{
The Use of Clay as a Methane Emission Mitigating Feed Additive in Djallonké Rams
}

\author{
Armel Laibi', Marcel Senou' ${ }^{2}$, Etienne Sagbo ${ }^{*}$, Mohamed Dahouda², Virgil Ahyi ${ }^{3}$, \\ Gado Tchangbedji ${ }^{4}$ \\ ${ }^{1}$ Faculté des Sciences et Techniques, Campus Universitaire d'Abomey-Calavi, Cotonou, Bénin \\ ${ }^{2}$ Faculté des Sciences Agronomiques, Campus Universitaire d'Abomey-Calavi, Cotonou, Bénin \\ ${ }^{3}$ Institut Régional du Génie Industriel des Biotechnologies, IRGIB Africa, Cotonou, Bénin \\ ${ }^{4}$ Faculté des Sciences, Université de Lomé, Lomé, Togo \\ Email: ${ }^{*}$ esagbo@yahoo.fr
}

Received 31 August 2015; accepted 25 October 2015; published 28 October 2015

Copyright (C) 2015 by authors and Scientific Research Publishing Inc.

This work is licensed under the Creative Commons Attribution International License (CC BY). http://creativecommons.org/licenses/by/4.0/

\section{(c) (i) Open Access}

\section{Abstract}

Four groups each composed of six rams with $15 \mathrm{~kg}$ average body weight were submitted to one of the following diet: Panicum maximum C1 (PM), Panicum maximum C1 plus concentrate (PM_Co), Panicum $m$. C1 plus clay (PM_Ar) and Panicum maximum C1 plus concentrate plus clay (PM_Co_Ar). The concentrate is composed of $90 \%$ weat bran, $9.25 \%$ cottonseed cake, $0.5 \%$ premix and 0.25 cooking salt. The clay used was a mixture of $59 \%$ smectite, $14 \%$ kaolinite and $27 \%$ quartz. The significance of treatments on variation in physico-chemical characteristics (ruminal $\mathrm{pH}$ and concentration of ammonia nitrogen), as well as in the rumen fermentation profile i.e. Volatile Fatty Acid concentration and in the enteric methane $\left(\mathrm{CH}_{4}\right)$ production, depending on the rumen fluid collection time (at 9 o'clock and 13 o'clock), were studied using AOV. The highest ruminal pH was recorded in animals fed the mixture of Panicum plus clay, which is $7.02 \pm 0.12$ against $6.96 \pm 0.12$, $6.8 \pm 0.06$ and $6.69 \pm 0.15$, respectively in animals fed with PM, PM_Co and PM_Co_Ar. Incorporation of clay in the mixture of Panicum C1 plus concentrate had a stabilizing effect on ruminal pH. A significant decrease in the concentration of ruminal $\mathrm{N}-\mathrm{NH}_{3}$ was recorded with PM_Ar $(56.6 \pm 15.2$ $\mathrm{g} / \mathrm{ml})$, compared to $\mathrm{PM}(89.0 \pm 18.9 \mathrm{~g} / \mathrm{ml})$. However, the ruminal $\mathrm{N}-\mathrm{NH}_{3}$ concentration of animals fed the PM_Co diet $(71.0 \pm 15.1 \mathrm{~g} / \mathrm{ml})$ increased in comparison to that of the PM_Co_Ar diet fed animals. Compared to the enteric methane concentration of the PM ration fed animals, the decrease of $\mathrm{CH}_{4}$ concentration was $2 \%-5 \%, 7 \%-11 \%$ and $19 \%-23 \%$ respectively in the PM_Ar, the PM_Co and the PM_Co_Ar diets fed rams. These results suggest that the methane reducing effect of clay might be emphasized by the concentrate supplementation of the diet.

\section{Keywords}

Greenhouse Gases, Djallonké Rams, Methanogenesis, Clay Supplementation

\footnotetext{
${ }^{*}$ Corresponding author.

How to cite this paper: Laibi, A., Senou, M., Sagbo, E., Dahouda, M., Ahyi, V. and Tchangbedji, G. (2015) The Use of Clay as a Methane Emission Mitigating Feed Additive in Djallonké Rams. Journal of Environmental Protection, 6, 1176-1185. 


\section{Introduction}

Feeding of ruminants in traditional low input systems is based, mainly on the use of roughage, generally poor in nitrogen, but rich in fiber [1]. By the rumen fermentation process, feed stuff is degraded with the ultimate production of methane that once expelled in the atmosphere, acts a greenhouse gas. Methane emission can be viewed as an energy loss for the animal as well as an economic loss for breeders [2]. With regard to its environmental impact, methane $\left(\mathrm{CH}_{4}\right)$ has a warming potential of about twenty-fold greater than that of carbon dioxide $\left(\mathrm{CO}_{2}\right)$. Although its concentration in the atmosphere is much lower than that of carbon dioxide, methane contributes about $20 \%$ to the overall greenhouse effect [3]. Agriculture alone contributes about $50 \%$ to all $\mathrm{CH}_{4}$ emissions globally, of which three quarters are due to rice cultivation and livestock production [4]. The present work aims to study the effect of dietary clay inclusion on the enteric methane emissions in Djallonké rams. For that we have used four diets with and without clay for four groups each composed of six rams. Clay is well known for its high cation exchange capacity (CEC) and its wealth in interlayer cations. The possibility of cation exchange ( $\mathrm{Ca}^{2+}$ and $\mathrm{Mg}^{2+}$ against the $\mathrm{H}^{+}$ions) corollary $\mathrm{pH}$ neutrality and the enrichment of rumen fluid with bivalent minerals [5]. Owing to the high CEC and buffering property of smectites like clay, it is thinkable that dietary inclusion of clay might be capable of causing an imbalance in favor of methanotrophic microbial activity in the rumen milieu. This is the rationale for the choice of clay as a methane emission mitigating feed additive.

\section{Material and Methods}

\subsection{Experimental Design and Treatments}

The experimental design was a one-way classification with six replicates of each treatment. The treatments considered correspond to the following diets: Panicum maximum C1 (PM), Panicum maximum C1 plus concentrate (PM_Co), Panicum maximum C1 plus clay (PM_Ar ) and Panicum maximum C1 plus concentrate plus clay (PM_Co_Ar). Each group composed of six rams were submitted to one of the four diets. The average body weight of experimental animals was $15 \mathrm{~kg}$. The treatment lasts 4 weeks preceded by 2 weeks adaptation phase. Experiment took place at the laboratory of Animal Science of the Faculty of Agriculture of the University of Abomey-Calavi. The concentrate is composed of $90 \%$ wheat bran, $9.25 \%$ cottonseed cake, $0.5 \%$ premix and 0.25\% sodium chloride. In the PM_Ar and PM_Co_Ar rations, the proportion of clay represents 5\% of the total dry matter. The clay used was a mixture of 59\% smectite, 14\% kaolinite and 27\% quartz [6] which was extracted from Gbedji-Kotovi deposit located in the Atlantic department of the Republic of Benin between $2^{\circ} 00^{\prime}$ and $2^{\circ} 02^{\prime}$ East longitude and $6^{\circ} 40^{\prime}$ and $6^{\circ} 42^{\prime}$ North latitude and at $5 \mathrm{~m}$ above sea level. The aveage CEC of the clay was $34.85 \mathrm{meq} / 100 \mathrm{~g}\left(\mathrm{Mg}^{2+}\right.$ (16.0286253), $\mathrm{Ca}^{2+}$ (16.330217), $\left.\mathrm{K}^{+}(0.91177598), \mathrm{Na}^{+}(1.57648702)\right)$ and its specific surface is $105.41 \mathrm{~m}^{2} / \mathrm{g}$.

Twice a day (at 09 o'clock and 13 o'clock), $15 \mathrm{ml}$ of rumen juice was extracted non-surgically from each experimental ram by the means of a probe of $94 \mathrm{~cm}$ length and $12 \mathrm{~mm}$ diameter and a $60 \mathrm{ml}$ syringe. All samples were collected by the same person. After each sample collection, the probe was rinsed thoroughly with warm water and then dried and lubricated with Vaseline. The $\mathrm{pH}$ of each sample was measured after collection using a $\mathrm{pH}$-meter. Then three drops of toluene were added to each sample to stop fermentation. The Rumen juice was filtered through a $1 \mathrm{~mm}$ sieve and then two aliquots were immediately frozen and stored at $-20^{\circ} \mathrm{C}$ in a refrigerator.

\subsection{Laboratory Analyses}

Determination of ammonia nitrogen $\left(\mathrm{N}-\mathrm{NH}_{3}\right)$ was performed by the modified method of Nessler. Instead of a spectrophotometer as in Nessler, ELISA chain was used to assay $\mathrm{N}_{-} \mathrm{NH}_{3}$. After thawing, samples were centrifuged at 16,000 g for $30 \mathrm{~min}$ to remove coarse particles. Then $400 \mu \mathrm{l}$ of Nessler's reagent was added to the supernatant which was previously diluted to 1/20th (1 $\mathrm{ml}$ of supernatant in $19 \mathrm{ml}$ of distilled water). Ten min after addition of Nessler's reagent, the absorbance and the concentration of $\mathrm{N}^{-\mathrm{NH}_{3}}$ were read at $420 \mathrm{~nm}$ using the ELISA system.

The crude protein (CP) content of the test rations were determined by the Kjeldahl method. Determination of volatile fatty acids (VFA) was performed using a gas chromatograph equipped with an auto injector (GC DANI). A capillary column in molten silica was used (Portlab P-DB5 $30 \mathrm{~m} \times 0.25 \mathrm{~mm} \times 0.25 \mu \mathrm{m}$ ).

The temperature of ionized flame detector was maintained at $280^{\circ} \mathrm{C}$ and that of the injector at $250^{\circ} \mathrm{C}$ with a split ratio of 40:1. The carrier gas was helium with a constant pressure of 24 psi and a flow of $1.8 \mathrm{ml} / \mathrm{min}$. The 
volume of sample injected was $1 \mu \mathrm{l}$. The initial oven temperature $\left(120^{\circ} \mathrm{C}\right)$ was maintained for $1 \mathrm{~min}$ and then increased by $10^{\circ} \mathrm{C} / \mathrm{min}$ to $250^{\circ} \mathrm{C}$. At $250^{\circ} \mathrm{C}$, the temperature was maintained for 5 minutes as described by Jaroslav F and Dvorak [7].

The analysis took approximately 15 minutes. The samples were thawed and then centrifuged at $4000 \mathrm{~g}$ for 20 minutes to remove the coarse particles. Deproteinization was performed by mixing $1 \mathrm{ml}$ of supernatant with 200 $\mu \mathrm{l}$ of the mixture metaphosphoric acid (25\% p/v) plus formic acid (3:1). After centrifugation at 16,000 g for 20 min, a sample of supernatant was taken and diluted to $1 / 10$ th. The methane production was estimated using the multiple regression equation along the lines with Demeyer [8].

\subsection{Statistical Analysis}

Significant tests of treatment effects on the $\mathrm{pH}$ and the fermentation profile were carried out by the GLM procedure of the SAS package. The model used was:

$$
y_{i j k}=\mu+\alpha_{i}+\beta_{j}+(\alpha \beta)_{i j}+e_{i j k}
$$

where $y_{i j k}$ is the observation on animal, $\mu$ the overall mean of observations, $\alpha_{i}$ the fixed effect of the ration used, $\beta_{j}$ the fixed effect of rumen fluid collection time, $(\alpha \beta)_{i j}$ the ration by rumen fluid collection time interaction and $e_{i j k}$ the residual. The dependent variables studied were: the ruminal $\mathrm{pH}$, the concentration of ammonia nitrogen, (in $\mathrm{mg} / \mathrm{L}$ ), that of the total volatile fatty acids (in $\mathrm{mmol} / \mathrm{L}$ ) as well as the centesimal composition of VFAs in acetic acid (C2\%), propionic acid (C3\%) and butyric acid (C4\%), the C2/C3 ratio and the concentration of enteric methane (in $\mu \mathrm{mol} / \mathrm{mmol}$ total VFAs). The significance tests of the presence of clay or that of the concentrate on the dependent variables were performed by linear contrasts. Mean comparisons of factor levels were performed by the Ryan-Einot-Gabriel-Welsch method.

\section{Results and Discussion}

Results from AOV are summarized in Table 1 and averages of physico-chemical characteristics and that of rumen fermentation profile, as affected by the factors: ration and rumen fluid collection time, are shown in Table 2. From AOV results (Table 1), it appears that the physico-chemical characteristics of the rumen fluid (pH and $\mathrm{N}-\mathrm{NH}_{3}$ concentration) as well as those of the rumen fermentation profile (VFAs and $\mathrm{CH}_{4}$ concentration), are significantly influenced by the ration. Also the rumen fluid collection time significantly influences the rumen $\mathrm{pH}$, the C2/C3 ratio and the $\mathrm{CH}_{4}$ production, but not the ammonia nitrogen concentration. There was no significant

Table 1. Significance test of the factors: ration, rumen fluid collection time, interaction (ration by sampling time) and test of the linear contrasts ("presence of clay versus absence of clay" and "presence of concentrate" versus "absence of concentrate") on physico-chemical characteristics of rumen fluid as well as rumen fermentation profile in Djallonké rams.

\begin{tabular}{|c|c|c|c|c|c|c|c|}
\hline & & Ration & Sampling time & Interaction\# & Contrast $^{1}$ & Contrast $^{2}$ & Model \\
\hline \multicolumn{8}{|c|}{ Physico-chemical characteristics } \\
\hline Rumen pH & $\mathrm{pH}$ & $* * *$ & $* * *$ & n.s & $* * *$ & n.s & $* * *$ \\
\hline Ammonia nitrogen (mg/l) & $\mathrm{N}-\mathrm{NH}_{3}$ & $* * *$ & n.s & n.s & $* * *$ & n.s & ** \\
\hline \multicolumn{8}{|c|}{ Characteristics of rumen fermentation profile } \\
\hline Total VFA (mmol/l) & VFA & ${ }^{* * *}$ & n.s & n.s & $* * *$ & n.s & ** \\
\hline Acetic acid (\%VFA) & $\mathrm{C} 2 \%$ & $* * *$ & ** & $* * *$ & $* * *$ & $* * *$ & $* * *$ \\
\hline Propionic acid (\%VFA) & $\mathrm{C} 3 \%$ & $* * *$ & $* * *$ & $* * *$ & $* * *$ & *** & $* * *$ \\
\hline Butyric acid (\%VFA) & $\mathrm{C} 4 \%$ & $* * *$ & n.s & $* * *$ & $* * *$ & *** & $* * *$ \\
\hline C2/C3 rate & $\mathrm{C} 2 / \mathrm{C} 3$ & $* * *$ & $* * *$ & $* * *$ & $* * *$ & *** & $* * *$ \\
\hline Methane $(\mu \mathrm{mol} / \mathrm{mmol}$ VFA) & $\mathrm{CH}_{4}$ & $* * *$ & $* * *$ & $* * *$ & $* * *$ & $* * *$ & $* * *$ \\
\hline
\end{tabular}

${ }^{*}=\mathrm{p}<0.05 ;{ }^{* *}=\mathrm{p}<0.01 ;{ }^{* * *}=\mathrm{p}<0.001 ; \mathrm{n} . \mathrm{s}=$ non-significant; $\#=$ interaction ration ${ }^{*}$ sampling time; ${ }^{1)}=$ contrast "presence of clay versus absence of clay"; ${ }^{2)}=$ contrast "presence of concentrate versus absence of concentrate". 
interaction found between the factors ration and rumen sampling time. However, the variation in the concentrations of volatile fatty acid compounds (acetic acid, propionic acid and butyric acid) as well as the C2/C3 ratio and the $\mathrm{CH}_{4}$ concentration are significantly affected by the interaction: ration by rumen fluid collection time. The test of the linear contrast: 'ration with clay versus ratio without clay' (PM, PM_Co versus PM_Ar, PM_Co_ $\mathrm{Ar}$ ) is highly significant $(\mathrm{p}<0.001)$ for the rumen $\mathrm{pH}$, the $\mathrm{N}_{-} \mathrm{NH}_{3}$ concentration and the characteristics of rumen fermentation profile (concentration of total VFAs, $\mathrm{C} 2 / \mathrm{C} 3$ ratio, $\mathrm{C} 2 \%, \mathrm{C} \%, \mathrm{C} 4 \%$ and $\mathrm{CH}_{4}$ concentration).

The contrast: 'ration with concentrate versus ration without concentrate' (PM_Co, PM_Co_Ar versus PM PM_Ar) is not significant for the variation in the rumen $\mathrm{pH}$, the concentration of $\mathrm{N}-\mathrm{NH}_{3}$ and that of the total VFA. However, this contrast is not significant for $\mathrm{C} 2 \%, \mathrm{C} 3 \%, \mathrm{C} 4 \%$, the $\mathrm{C} 2 / \mathrm{C} 3$ ratio and the $\mathrm{CH}_{4}$ concentration.

\subsection{The Ruminal pH}

The $\mathrm{pH}$ of the rumen fluid collected at 09 o'clock a.m. is higher than that collected at 13 o'clock in all rams fed the ration PM, PM_Co and PM_Ar. Only the PM_Co_Ar ration has undergone no significant decrease in pH from 09 o'clock to 13o'clock (Figure 1).

Ruminal pH associated to the two rations without concentrate (PM and PM_Ar) are significantly higher than that recorded in the rations containing concentrate (PM_Co and PM_Co_Ar). Regardless of the sampling time, the highest $\mathrm{pH}$ was recorded in the rumen of with PM_Ar ration fed rams, followed by those obtained in the rumen of with PM, PM_Co and PM_Co_Ar fed ones in decreasing order of pH values (Figure 2). These results

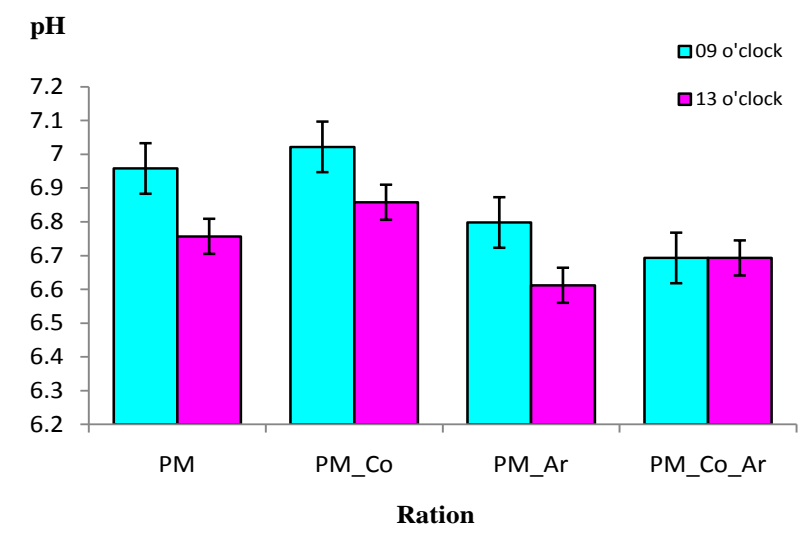

Figure 1. Averages of ruminal $\mathrm{pH}$ in Djallonké rams, as influenced by the ration and the rumen fluid collection time.

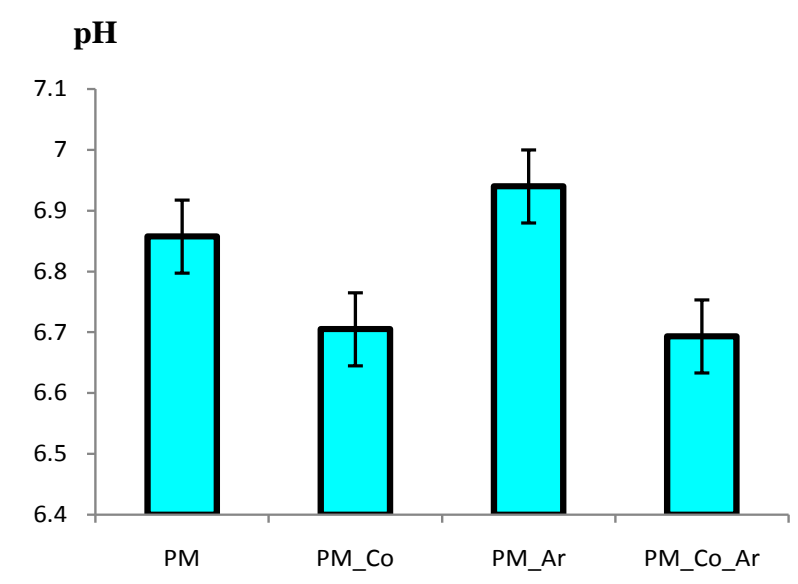

Ration

Figure 2. Averages of ruminal $\mathrm{pH}$ in Djallonké rams as affected by the type of ration. 
indicate that clay incorporation into Panicum C1 hay induces an increase in the numinal pH toward the neutrality threshold. On the other hand, the joint effect of clay and concentrate in the PM_Co_Ar ration had led to the stability of numen $\mathrm{pH}$. As a consequence, the rumen $\mathrm{pH}$ remained unchanged in the rams fed the PM_Co_Ar diet, regardless of the rumen fluid collection time. It should be noted that no cases of acidosis $(\mathrm{pH}<5)$ were observed in rams subjected to the different diets studied. The neutrality of $\mathrm{pH}$ observed, even after a meal with PM_Ar ration, is very conducive to optimal cellulolytic and proteolytic activities [9]. The stability of ruminal pH in rams fed with PM_Co_Ar is very favourable to the degradation of the fibers in the ration. This clay effect on the ruminal $\mathrm{pH}$ is attributable to the high cation exchange capacity and buffering property of Smectites. Indeed, Smetites peform inter foliar cation exchange between $\left(\mathrm{Ca}^{2+}\right.$ and $\left.\mathrm{Mg}^{2+}\right)$ and $\mathrm{H}^{+}$ions in excess in the rumen liquid. The subsequent $\mathrm{H}+$ ions depletion in turn, lead to the increase of rumen $\mathrm{pH}$. In other words, Smectites buffers the rumen liquid and enriches it with minerals which are useful for the attachment of cellulolytic flora to vegetal particles. Thus Fonty et al. [10] reported that the presence of $\mathrm{Ca}^{2+}$ and $\mathrm{Mg}^{2+}$ in the rumen is favorable to the cellulose degradation by bacteria. Moreover De Smith and Demeyer [11] showed that in sacco degradation of dry matter of straw increases with increasing $\mathrm{pH}$. This finding is consistent with the increase of rumen $\mathrm{pH}$ observed in our experiment with rams fed with clay incorporated Panicum C1 hay.

\subsection{Ammonia Nitrogen}

In the rumen fluid collected at 9 o'clock am on animals fed with Panicum C1 hay only, the concentration of $\mathrm{N}-\mathrm{NH}_{3}$ is higher than that recorded in the rumen fluid collected at 13 o'clock, while for animals fed Panicum plus clay or Panicum plus concentrate or Panicum plus concentrate plus clay, the concentration of $\mathrm{N}-\mathrm{NH}_{3}$ is lower in the rumen fluid collected at $9 \mathrm{~h}$ compared to that collected at 13 o'clock (Figure 3). Subsequent Means comparison to AOV indicated a significant decline of rumen $\mathrm{N}_{-} \mathrm{NH}_{3}$ concentration in the PM_Ar fed animals compared to that of PM fed ones. Similarly, the presence of both concentrate and clay in the ration PM_Co_Ar induced a decrease of the rumen $\mathrm{N}-\mathrm{NH}_{3}$ concentration compared to that recorded in animals fed with PM_Co. Corresponding results are illustrated by Figure 4.

Compared to the PM ration, the PM_Co ration has higher crude protein content. Degradation of crude protein induces first an enrichment of the rumen medium with ammonia nitrogen, which in turn is used for microbial protein synthesis. This probably explains the decrease of the ruminal $\mathrm{N}-\mathrm{NH}_{3}$ concentration after 4 hours rumination in rams subjected to the PM_Co ration. It is well known that ammonia nitrogen results from protein degradation as well as from recycling of urea and from bacterial lysis. $\mathrm{N}_{-} \mathrm{NH}_{3}$ is removed from the rumen, ensuing microbial protein synthesis and absorption by the rumen wall [12]. Offner et al. [13] also showed that ammonium nitrogen can come from the soluble proteins ( $26 \%$ of the crude protein). The decrease of the rumen $\mathrm{N}-\mathrm{NH}_{3}$

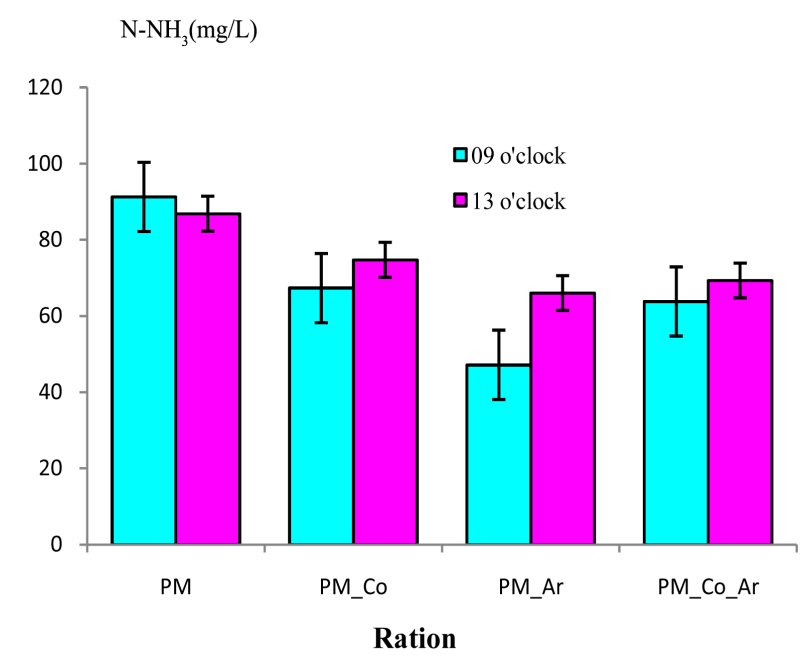

Figure 3. Average concentrations of rumen ammonia nitrogen in Djallonké rams, as influenced by the ration and the rumen fluid collection time. 
$\mathrm{N}-\mathrm{NH}_{3}(\mathrm{mg} / \mathrm{L})$

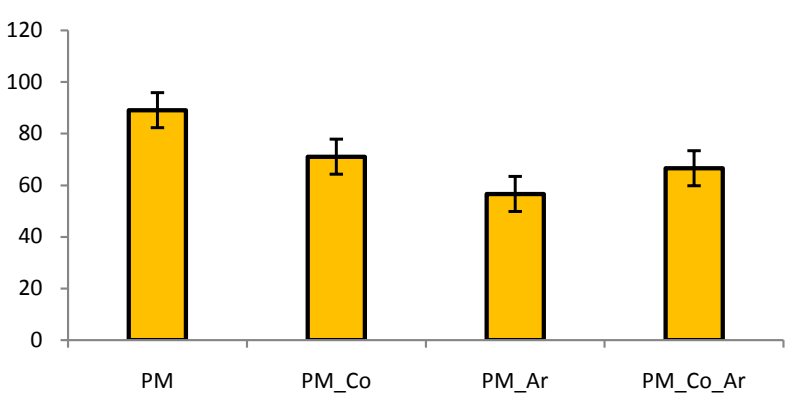

Ration

Figure 4. Average concentrations of rumen ammonia nitrogen in Djallonké ramsas affected by the type of ration.

concentration associated with the consumption of PM_Ar and PM_Co_Ar rations, compared to the PM and PM_Co ones in our experience, is in agreement with the results of Ben Ahmed and Dulphy [14] and Dulphy et al. [15]. The concentration of ammonia nitrogen released in the rumen with PM_Co was much greater than the value of $50 \mathrm{mg} / \mathrm{L}$ considered as the upper limit for a good functioning rumen [16]. Decrease of ruminal $\mathrm{NH}_{3}-\mathrm{N}$ concentration in animals subjected to the clay incorporated rations (PM_Ar and PM_Co_Ar), is therefore a comparative advantage of the latter's against the rations without clay (PM and PM_Co). This decrease may be attributed to the high adsorption capacity of the Smectite-like clays. Indeed, the nitrogen supplied by the PM_Co ration was immediately adsorbed by the clay. Clay can well play a key role in the nitrogen savings in the rations with explosive ammoniogenesis [5].

\subsection{Characteristics of the Rumen Fluid Fermentation Profile (VFA and $\mathrm{CH}_{4}$ )}

The characteristics of the rumen fluid fermentation profile in terms of VFAs and CH4 concentration, depending on the ration type and the rumen fluid collection time are shown in Table 2. In animals fed with PM and collected at 09 o'clock, the average concentration of total VFA $(69.1 \mathrm{mmol} / \mathrm{L})$ is significantly higher than those recorded in animals fed with PM_Co $(58.8 \mathrm{mmol} / \mathrm{L})$ or with PM_Ar $(51.1 \mathrm{mmol} / \mathrm{L})$ or with PM_Co_Ar $(60.5$ $\mathrm{mmol} / \mathrm{L}$ ). There was a significant decrease of the enteric methane concentration by the clay supplementation of Panicum irrespective of the rumen sampling time (Figure 5 and Figure 6).

The decrease in the concentration of enteric methane production associated with the dietary inclusion of clay is much enhanced by the presence of concentrate (Figure 7).

Compared to the volume of enteric methane in the PM ration fed animals, the decrease rates were $2 \%$ to $5 \%$, $7 \%$ to $11 \%$ and $19 \%$ to $23 \%$ respectively in those fed the PM_Ar, the PM_Co and the PM_Co_Ar rations. The reduction rates of enteric $\mathrm{CH} 4$ production were significantly higher in animals collected at $13 \mathrm{~h}$ than those taken at $9 \mathrm{~h}$. Results in Table 2 also suggest that the reduction of $\mathrm{CH}_{4}$ production is closely related to a significant decrease in the $\mathrm{C} 2 / \mathrm{C} 3$ ratio, reflecting an increase in the C3 concentration at the expense of the $\mathrm{C} 2$ one. In a normally fermenting and stable rumen, that is to say, in animals fed with fiber rich diets, the proportions of VFA are generally about $66 \%, 19 \%$ and $11 \%$ for the acetic, the propionic and the butyric acids respectively [17]. The C2/C3 rate of such a profile is about 3.5 ([17] [18]). These authors found that the C2/C3 ratio of a normal functioning rumen should exceed the value of 3 . With reference to this author, we can state, that the rumen function is normal in the rams fed with PM and PM_Co PM_Ar, because in these rations, the C2/C3 ratio were greater than 3. Addition of the protein concentrate to the Panicum hay (PM_Co diet) caused an increase in propionic acid at the expense of acetic acid, which results in a reduction in the C2/C3 ratio. This positive effect of the concentrate is in agreement with the results of [18] according to which, the proportion of metabolizable energy loss ensuing methane production decreases significantly, when the proportion of concentrate (or grain) in the diet exceed $40 \%$. The decrease of the $\mathrm{C} 2 / \mathrm{C} 3$ ratio in the presence of the concentrate appears to enhance the 
CH

$\mu \mathrm{mol} / \mathrm{mmol}$ of

VFA
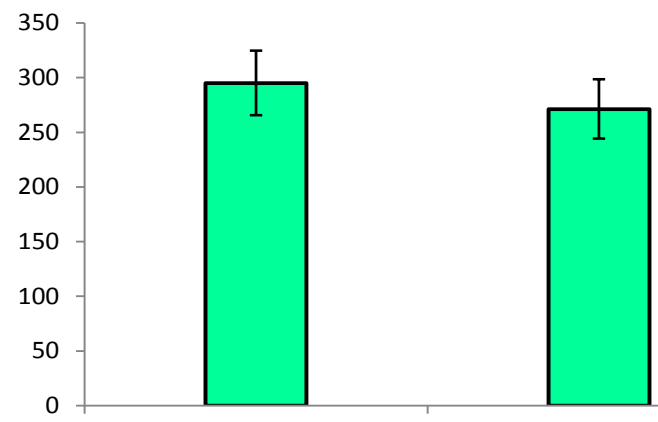

no

yes

Presence of clay

Figure 5. Average concentrations of enteric methane in diets with or without clay supplementation.

\section{$\mathrm{CH}_{4} \mu \mathrm{mol} / \mathbf{m m o l}$}

of VFA

口with clay $\square$ without clay

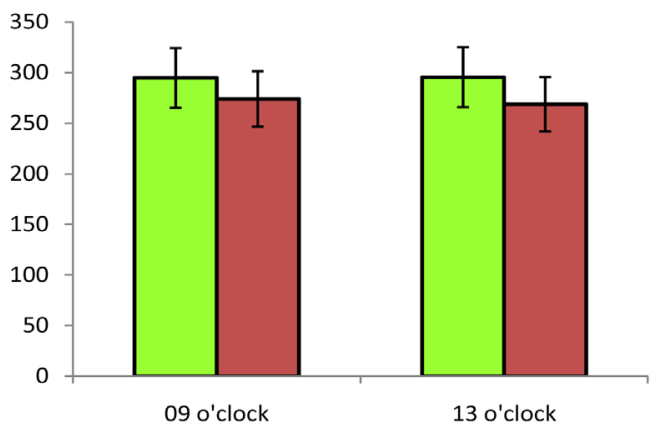

Rumen fluid sampling time

Figure 6. Average concentrations of enteric methane according to the rumen fluid sampling time in animals fed with clay supplemented diets or not.

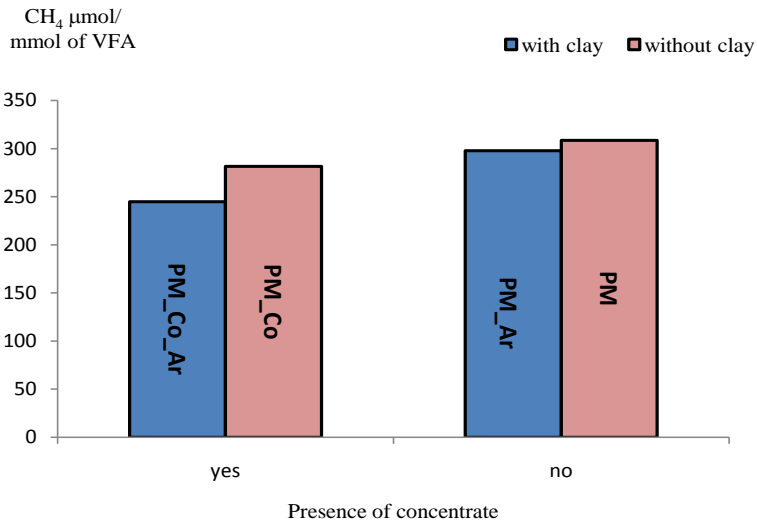

Figure 7. Averages of enteric methane production as effected by the clay and or concentrate inclusion in the diet. 
Table 2. Means of the rumen $\mathrm{pH}$, that of the ammonia nitrogen concentration $\left(\mathrm{N}_{-} \mathrm{NH}_{3}\right)$, the volatile fatty acid concentration (total VFA, C2, C3, C4) as well as the enteric methane concentration $\left(\mathrm{CH}_{4}\right)$ as affected by the ration and the rumen fluid collection time (sampling time $1=9 \mathrm{~h}$; sampling time $2=13 \mathrm{~h}$ ) in Djallonké rams.

\begin{tabular}{|c|c|c|c|c|c|c|c|}
\hline & & $\mathrm{PM}$ & PM_Ar & PM_Co & PM_Co_Ar & $\mathrm{p}$ & SEM \\
\hline \multicolumn{8}{|c|}{ Sampling time 1} \\
\hline Rumen $\mathrm{pH}$ & $\mathrm{PH}$ & $6958^{\mathrm{a}}$ & $7022^{\mathrm{a}}$ & $6798^{\mathrm{b}}$ & $6693^{\mathrm{b}}$ & 0.0001 & 0.339 \\
\hline Ammonia nitrogen (mg/l) & AAM & $91,237^{\mathrm{a}}$ & $47,147^{\mathrm{b}}$ & $67,317^{\mathrm{b}}$ & $63,797^{b}$ & 0.0005 & 4.298 \\
\hline Total VFA (mmol/l) & VFA & $69,083^{\mathrm{a}}$ & $51,083^{\mathrm{b}}$ & $58,783^{\mathrm{ab}}$ & $60,467^{\mathrm{ab}}$ & 0.0081 & 2.015 \\
\hline Acetic acid (\%VFA) & $\mathrm{C} 2 \%$ & $68,200^{\mathrm{a}}$ & $68,100^{\mathrm{a}}$ & $66,100^{\mathrm{b}}$ & $58,500^{c}$ & $<0.0001$ & 0.828 \\
\hline Propionic Acid (\%VFA) & С $3 \%$ & $13,167^{\mathrm{d}}$ & $17,900^{\mathrm{c}}$ & $19,900^{\mathrm{b}}$ & $20,467^{\mathrm{a}}$ & $<0.0001$ & 0.599 \\
\hline Butyric acid (\%VFA ) & $\mathrm{C} 4 \%$ & $8533^{c}$ & $10,500^{\mathrm{a}}$ & $10,500^{\mathrm{a}}$ & $10,367^{\mathrm{b}}$ & $<0.0001$ & 0.175 \\
\hline $\mathrm{C} 2 / \mathrm{C} 3$ ratio & $\mathrm{C} 2 / \mathrm{C} 3$ & $5180^{\mathrm{a}}$ & $3804^{\mathrm{b}}$ & $3322^{\mathrm{c}}$ & $2859^{d}$ & $<0.0001$ & 0.181 \\
\hline Methane ( $\mu \mathrm{mol} / \mathrm{mmol}$ VFA) & $\mathrm{CH} 4$ & $304,825^{\mathrm{a}}$ & $299,225^{\mathrm{b}}$ & $284,725^{c}$ & $248,433^{\mathrm{d}}$ & $<0.0001$ & 4.583 \\
\hline \multicolumn{8}{|c|}{ Sampling time 2} \\
\hline Rumen $\mathrm{pH}$ & $\mathrm{PH}$ & $6757^{\mathrm{ab}}$ & $6858^{\mathrm{a}}$ & $6612^{\mathrm{b}}$ & $6693^{\mathrm{ab}}$ & 0.0271 & 0.031 \\
\hline Ammonia Nitrogen (mg/l) & AAM & $86,830^{\mathrm{a}}$ & $66,010^{c}$ & $74,730^{\mathrm{b}}$ & $69,290^{\mathrm{ab}}$ & 0.02127 & 3.720 \\
\hline Total VFA (mmol/l) & VFA & $68,383^{\mathrm{a}}$ & $55,717^{\mathrm{b}}$ & $62,850^{\mathrm{ab}}$ & $59,500^{\mathrm{ab}}$ & 0.00658 & 1.782 \\
\hline Acetic acid (\%VFA) & $\mathrm{C} 2 \%$ & $70,517^{\mathrm{a}}$ & $67,433^{\mathrm{b}}$ & $65,900^{c}$ & $56,700^{d}$ & $<0.0001$ & 1.074 \\
\hline Propionic acid (\%VFA) & С3\% & $14,750^{\mathrm{d}}$ & $18,483^{\mathrm{c}}$ & $19,900^{\mathrm{b}}$ & $21,200^{\mathrm{a}}$ & $<0.0001$ & 0.504 \\
\hline Butyric acid (\%VFA) & $\mathrm{C} 4 \%$ & $8,933^{\mathrm{d}}$ & $10,900^{\mathrm{b}}$ & $9100^{\mathrm{c}}$ & $11,100^{\mathrm{a}}$ & $<0.0001$ & 0.208 \\
\hline $\mathrm{C} 2 / \mathrm{C} 3$ ratio & $\mathrm{C} 2 / \mathrm{C} 3$ & $4781^{\mathrm{a}}$ & $3648^{\mathrm{b}}$ & $3312^{c}$ & $2675^{\mathrm{d}}$ & $<0.0001$ & 0.159 \\
\hline Methane $(\mu \mathrm{mol} / \mathrm{mmol}$ VFA) & $\mathrm{CH} 4$ & $312,496^{\mathrm{a}}$ & $296,221^{b}$ & $278,225^{c}$ & $241,250^{d}$ & $<0.0001$ & 5.525 \\
\hline
\end{tabular}

a b , c, d means with the same superscript are not significantly different at $5 \%$ confidence limit.

effect of dietary clay addition. As a consequence, the decrease in the $\mathrm{CH}_{4}$ production in the PM_Co_Ar fed rams is much more pronounced compared to all other diets.

In the present experiment, dietary clay inclusion has significantly shifted the orientation of fermentation toward a much lower $\mathrm{C} 2 / \mathrm{C} 3$ ratio and a slightly higher $\mathrm{C} 4 \%$. Improvement of feed intake and digestibility might be the consequence of the significant drop in the C2/C3 ratio [16]. In the present work, the C2/C3 ratio (2.67) associated with the consumption of clay incorporated diets is significantly lower than the values reported by [1] (2.91) and [15] (3.79 to 4.05). It should be noted that in their experiments, the diet used by the first author consisted of with urea treated straw plus clay, while the diet tested by second author was a urea-treated straw with or without addition of soy molasses.

The decrease in the C2/C3 ration in our experiment with the PM_Co_Ar diet has resulted in a significant decrease in methane production ( $\mathrm{p}<0.001$ ). Indeed, carbohydrate polymers (cellulose, hemicellulose, starch etc.) are degraded into simple molecules, the oligosaccharides and then the monosaccharides with 5 or 6 carbon atoms (C). These monosaccharides are then metabolized within microbial cells by the process of glycolysis resulting in 3C molecules among which the pyruvic acid which constitutes a "metabolic crossroads". From the latter, several fermentation pathways may take place in the rumen, leading predominantly to the formation of volatile fatty acids (VFA): acetic acid (C2), propionic acid (C3) and butyric acid (C4) [18]. These different pathways of degradation and fermentation process are associated with the synthesis and/or the use of molecular hydrogen transporters (denoted by $\mathrm{H}_{2}$ bound to its transporter) as well as the use of energy in the form of ATP and loss of carbon (C). Methane production is part of the rumen fermentation processes. Methane is synthesized by methanogen microorganisms, the Archaea, according to the following reaction which is high consumer of $\mathrm{H}_{2}$ : $\mathrm{CO}_{2}+8 \mathrm{H}_{2} \rightarrow \mathrm{CH}_{4}+\mathrm{H}_{2} \mathrm{O}+1 \mathrm{ATP}$. The use of hydrogen can still lead to two other reactions, resulting in either 
acetate or propionate in accordance with the following equations: $\mathrm{CO}_{2}+8 \mathrm{H}_{2} \rightarrow$ acetate $+2 \mathrm{H}_{2} \mathrm{O}+0.25 \mathrm{ATP}$ (acetogenesis) or 2[pyruvate] $+4 \mathrm{H}_{2} \rightarrow 2$ [propionate] $+2 \mathrm{H}_{2} \mathrm{O}$. In our experiment, the $\mathrm{C} 2 / \mathrm{C} 3$ ratio favors the production of propionate. The clay used might thus have an inhibitory effect on the activity of methanogenic microorganisms or could have shifted fermentation towards the propionate path. Biological methane production results from the balance between the production of this gas by methanogenic Archaea and its oxidation by methanotrophic microorganisms. It is also thinkable, that other feed additives might be capable of causing the imbalance in favor of methanotrophic microbial activity. Thus Leng et al. [19] has shown in an in vitro experiment, that the incorporation of organic carbon alone or in combination with nitrate as non-protein nitrogen source, is likely to cause a reduction in enteric methane production ( $40.5 \%$ to $49 \%)$. In the present study, the proportion of clay incorporated into the diets represents $5 \%$ of the total dry matter of the ration. A greater reduction in the concentration of enteric methane is still possible by varying the concentration of clay in the PM_Ar and PM_Co_Ar rations.

\section{Conclusion}

From the results of the present study, it appears that dietary inclusion of clay with high CEC in fiber rich feedstuff such as Panicum hay is relevant for an environmentally friendly feeding in sheep. Indeed, the enrichment of rumen fluid with cations, due to the presence of clay, supports the cellulolytic degradation by rumen microorganisms. Furthermore, the presence of Smectic like clay induces a decrease of ammonia nitrogen concentration, which emphasizes the nitrogen savings ability of clay. Addition of clay to the Panicum hay induces a decrease of enteric methane production in Djallonké rams. This decrease is much more significant (21\%) in the presence of both clay and protein concentrate in the diet.

\section{References}

[1] Ouachem, D., Soltane, M. and Kalli, A. (2008) Les pailles de céréales: Profil des fermentations et production de méthane. Sciences \& Technologie, 27, 23-28.

[2] Chenoweth, D.P. (1996) Environmental Impact of Methanogenesis. Environmental Monitoring and Assessment, 42, 3-18. http://dx.doi.org/10.1007/BF00394039

[3] Jouany, J.-P. and Thivend, P. (2008) La production de méthane d'origine digestive chez les ruminants et son impact sur le réchauffement climatique. Management \& Avenir, 6, 259-274. http://dx.doi.org/10.3917/mav.020.0259

[4] CITEPA (2010) Inventaire des émissions de polluants atmosphériques en France. Séries sectorielles et analyses étendues. Format SECTEN, Rapport National d'Inventaire, 316.

[5] Ouachem, D. and Ghamri, N. (2002) Effets de l'argile sur la digestibilité du foin et la croissance chez les Ovins. Revue Sciences Agronomiques et Forestières, 1.

[6] Laibi, B.A. (2008) Caractérisation physicochimique et minéralogique de quelques échantillons d'argile du bassin sédimentaire côtier du Bénin. Mémoire de DEA, Université d’Abomey Calavi, 80.

[7] Jaroslav, F. and Dvorak, R. (2009) Determination of Volatile Fatty Acid Content in the Rumen Liquid: Comparison of Gas Chromatographiy and Capillary Isotachophoresis. Acta Veterinaria Brno, 78, 627-633. http://dx.doi.org/10.2754/avb200978040627

[8] Demeyer, D.I. (1991) Quantitative Aspects of Microbial Metabolism in the Rumen and Hindgut. In: Jouany. J.P., Ed., Rumen Microbial Metabolism and Ruminant Digestion, Editions INRA Paris, 217-237.

[9] Erfle, J.D., Boila, R.J., Teather, R.M., Mahadevan, S. and Sauer, F.D. (1982) Effect of pH on Fermentation Characteristics and Protein Degradation by Rumen Micro-Organisms in Vitro. Journal of Dairy Science, 65, 1457-1464. http://dx.doi.org/10.3168/jds.S0022-0302(82)82368-0

[10] Fonty, G., Jouany, J.P., Forano, E. and Gouet, P.H. (1995) Nutrition des ruminants domestiques: L'écosystème microbien du réticulo-rumen. Editions INRA, 299-348.

[11] De Smith, S. and Demeyer, D.I. (1992) Dégradabilité in sacco: Variabilité entre animaux. Annales de Zootechnie, 41, 21-22. http://dx.doi.org/10.1051/animres:19920107

[12] Philippeau, C., Landry, J. and Michalet-Doreau, B. (2000) Influence of the Protein Distribution of Maize Endosperm on Ruminal Starch Degradability. Journal of the Science of Food and Agriculture, 80, 404-408. http://dx.doi.org/10.1002/1097-0010(200002)80:3<404::AID-JSFA541>3.0.CO;2-Z

[13] Offner, A., Chapoutot, P. and Sauvant, D. (2002) Comparaison de trois modèles du rumen sur leur aptitude à prédire la digestion des glucides pariétaux et amylacés. $9^{\text {ème }}$ Rencontre Recherche Ruminants, Paris, 4-5 Décembre $2002,336$.

[14] Ben Ahmed, H. and Dulphy, J.P. (1987) Influence de la complémentation des foins traités à l'ammoniac sur la valeur 
nutritive. Annales de Zootechnie, 36, 153-170. http://dx.doi.org/10.1051/animres:19870205

[15] Dulphy, J.P., Jamot, J., Chenost, M., Besle, J.M. and Chiofalo, V. (1992) The Influence of Urea Treatment on the Intake of Wheat Straw in Sheep. Annales de Zootechnie, 41, 169-185. http://dx.doi.org/10.1051/animres:19920205

[16] INRA (1978) Alimentation des ruminants. INRA Publication, Versailles, 597 p.

[17] Sauvant, D. and Peyraud, J.L. (2010) Calculs de ration et évaluation du risque d'acidose. Inra Production Animale, 23, 333-342.

[18] Sauvant, D., Giger-Reverdin, S. and Serment Broudiscou, L. (2011) Influences des régimes et de leur fermentation dans le rumen sur la production de méthane par les ruminants. INRA Production Animale, 24, 433-446.

[19] Leng, R.A., Inthapanya, S. and Preston, T.R. (2012) Biochar Lowers Net Methane Production from Rumen Fluid in Vitro. Livestock Research for Rural Development, 24, Article \#103. http://www.lrrd.org/lrrd246/sang24103.htm 